\title{
Preface: Advances in meteorological hazards and extreme events
}

\author{
Panagiotis T. Nastos ${ }^{1}$ and Nicolas R. Dalezios ${ }^{2}$ \\ ${ }^{1}$ Laboratory of Climatology and Atmospheric Environment, National and Kappodistrian University of Athens, Athens, Greece \\ ${ }^{2}$ University of Thessaly, Volos, Greece
}

Correspondence to: Panagiotis T. Nastos (nastos@geol.uoa.gr)

Published: 31 May 2016

This Special Issue of the Natural Hazards and Earth System Sciences (NHESS) entitled "Advances in Meteorological Hazards and Extreme Events" hosts fifteen (15) selected papers presented at the 11th International Conference on Meteorology, Climatology and Atmospheric Physics - COMECAP 2012 - Athens, 29 May-1 June 2012. COMECAP 2012 covered various topics related to the science of the Atmospheric Environment, which is in fact an interdisciplinary field, giving the opportunity to understand the physical systems and environmental processes in an integrated manner. The featured papers shed light to advances and current trends in the considered meteorological hazards and extreme events, such as tornadoes, heat waves and extreme temperature indices, droughts, floods, convective precipitation, landslides, medicanes (Mediterranean tropical like cyclones) and wildfires, using recorded datasets, model simulations and innovative methodologies.

Hazard (or cause) may be defined as a potential threat to humans and their welfare and risk (or consequence) as the probability of a hazard occurring and creating loss. Unlike hazard and risk, a disaster is an actual happening, rather than a potential threat, thus, a disaster may be defined as the realization of hazard. The term environmental hazard has the advantage of including a wide variety of hazard types ranging from natural (geophysical) events, through technological (man-made) events to social (human behaviour) events. Meteorological hazards and extremes constitute natural environmental hazards caused by atmospheric disturbances. Disaster risk arises when hazards interact with physical, social, economic and environmental vulnerabilities. The impact of disaster can be transferred from one region to another. This, compounded by increasing vulnerability related to several factors, such as population growth, land pressure, urbanization, social inequality, climate change, political change, economic growth, technological innovation, social expectations, global interdependence, environmental degradation, competition for scarce resources and the impact of epidemics, points to a future where disasters could increasingly threaten, among others, the sustainable development of agricultural regions (Smith, 2013). Sustainable development, socio-economic improvement, good governance, and disaster risk reduction are mutually supportive objectives.

Recent research findings suggest that variability of climate, if encompassing more intense and frequent extremes, such as major large-scale environmental hazards like droughts, heatwaves or floods, results in the occurrence of natural disasters that are beyond our socio-economic planning levels. This is expected to stretch regional response capabilities beyond their capacity and will require new adaptation and preparedness strategies (Salinger et al., 2005). Disaster prevention and preparedness should become a priority and rapid response capacities to climate change need to be accompanied by a strategy for disaster prevention. Nevertheless, each type of extreme events has its own particular climate, cultural and environmental setting, and mitigation activities must use these settings as a foundation of proactive management. There is an urgent need to assess the forecasting skills for natural disasters affecting mainly agriculture and other sectors of the economy in order to determine those where greater research is necessary. It is well known that lack of good forecast skill is a constraint to improve adaptation, management and mitigation. Seasonal to interannual climate forecasting is a new branch of climate science, which promises reducing vulnerability. Improved seasonal forecasts are now being linked to decision making for cropping. The application of climate knowledge to the improvement of risk management is expected to increase the resilience of farming systems.

A more integrated approach to environmental hazards has been gradually attempted using common methodologies, 
such as risk analysis. Understanding of extreme events and disasters is a pre-requisite for the development of adaptation strategies in the context of climate change and risk reduction within the disaster risk management framework (IPCC, 2012). Extreme events will have greater impacts on sectors with closer links to climate, such as agriculture and food security. According to the World Meteorological Organization (WMO, 2006), some natural hazards are weather events (tropical and extra-tropical cyclones, tornadoes, thunderstorms, lightning, hailstorms, high winds, snow storms, freezing rain, dense fog, thermal extremes and drought). Others are related to weather, climate and water (floods and flash floods, storm surges, high waves at sea, sand- or dust storms, forest or bush fires, smoke and haze, landslides and mudslides, avalanches and desert locust swarms). Each hazard is in some way unique. Tornadoes and flash floods are shortlived, violent events, affecting a relatively small area. Others, such as droughts, develop slowly, but can affect most of a continent and entire populations for months or even years. An extreme weather event can involve multiple hazards at the same time or in quick succession. In addition to high winds and heavy rain, a tropical storm can result in flooding and mudslides. In temperate latitudes, severe summer weather (thunder and lightning storms or tornadoes) can be accompanied by heavy hail and flash floods. Winter storms with high winds and heavy snow or freezing rain can also contribute to avalanches on some mountain slopes and to high runoff or flooding later on in the melt season.

The special issue "Advances in meteorological hazards and extreme events" reflects a wide range of papers analyzing meteorological hazards and extreme events mainly in the Mediterranean area, using recorded data sets, model simulations and innovative methodologies. This special issue provides advances and current trends in the considered meteorological hazards and extreme events, such as tornadoes, heat waves and extreme temperature indices, droughts, floods, convective precipitation, landslides, medicanes (Mediterranean tropical like cyclones) and wildfires. We considered useful to adopt six sub-sections in the structure of the text associated with the aforementioned extremes discussed in the Special Issue. At the beginning of each section, the features of the meteorological hazards and extreme events are briefly described, followed by the presentation of the related research in the Special Issue.

i. Tornadoes are extreme phenomena associated with severe convective storms. The Greek philosopher Aristotle (384-322 BC) in Meteorologica presented perhaps the most renowned exposition of natural extreme phenomena: "So the whirlwind originates in the failure of an incipient cyclone to escape from its cloud. It is due to the resistance the eddy generates and emerges when the spiral descends to the earth dragging along the cloud that cannot shake off. When blowing in a straight line it carries along whatever comes by in a circular mo- tion and overturns and snatches up whatever it meets" (Meteorologica, 371a9-15). Tornadoes occur in many parts of the world (Fujita, 1973). Several publications during the last several decades have presented historical records concerning tornadic activity (e.g. Meaden, 1976; Tooming et al. (1995); Peterson, 1998; Reynolds, 1999; Gayà et al., 2000; Tyrrel, 2003; Macrinoniene, 2003; Dotzek, 2003; Nastos and Matsangouras, 2010; Brázdil et al., 2012; Rahuala et al., 2012; Matsangouras et al., 2014a). Two papers in the Special Issue present synoptical analysis and modeling simulations of tornadoes over Greece.

More specifically, a synoptic analysis of tornadic events (tornadoes, waterspouts and funnel clouds) over western Greece by means of composite means and anomalies of synoptic conditions is conducted by Nastos and Matsangouras (2014). The daily composite means of synoptic conditions are based on the National Centers for Environmental Prediction-National Center for Atmospheric Research (NCEP-NCAR) reanalysis data sets, for the period 12 August 1953 to 31 December 2012. The daily composite anomalies are calculated with respect to 30 years of climatological study (1981-2010) of the synoptic conditions. The analysis is carried out in terms of seasonal and monthly variability of composite means and anomalies of synoptic conditions for specific isobaric levels of $500,700,850,925 \mathrm{hPa}$ and the sea level pressure (SLP). In addition, an evaluation of the dynamic lifted index from NCEP-NCAR reanalysis data sets is presented. The daily composite mean analysis of $500 \mathrm{hPa}$ reveals a trough line across the northern Adriatic Sea and central Italy, associated with a SW upper-air stream over western Greece. The maximum composite anomalies are depicted at the isobaric level of $500 \mathrm{hPa}$ during autumn, spring and summer, against winter when the anomaly appears at $925 \mathrm{hPa}$ isobaric level. In addition, $48 \%$ of tornado events during the autumn season occur in pre-frontal weather conditions (cold fronts) and $27 \%$ developed after the passage of the cold front. Furthermore, the main difference in synoptic patterns between tornado and waterspout days along western Greece during the autumn season is the maximum daily composite anomaly over the Gulf of Taranto.

The role of topography in significant tornadogenesis events triggered under strong synoptic scale forcing over Greece is investigated by Matsangouras et al. (2014b). Three tornado events that occurred over the last years in Thebes (Boeotia, 17 November 2007), Vrastema (Chalkidiki, 12 February 2010) and Vlychos (Lefkada, 20 September 2011) are selected for numerical experiments. These events are associated with synoptic scale forcing, while their intensities were T4-T5 (on the TORRO scale), causing significant damage. The 
simulations are performed using the non-hydrostatic weather research and forecasting model (WRF), initialized by European Centre for Medium-Range Weather Forecasts (ECMWF) gridded analyses, with telescoping nested grids that allow for the representation of atmospheric circulations ranging from the synoptic scale down to the mesoscale. In the experiments, the topography of the inner grid is modified by: (a) $0 \%$ (actual topography) and (b) $-100 \%$ (without topography), making an effort to determine whether the occurrence of tornadoes - mainly identified by various severe weather instability indices - could be indicated by modifying topography. The principal instability variables employed consist of the bulk Richardson number (BRN) shear, the energy helicity index (EHI), the storm-relative environmental helicity (SRH), and the maximum convective available potential energy (MCAPE, for parcels with maximum $\theta_{\mathrm{e}}$ ). Additionally, a model verification is conducted for every sensitivity experiment accompanied by analysis of the absolute vorticity budget. $\mathrm{Nu}-$ merical simulations reveal that the complex topography constitutes an important factor during the 17 November 2007 and 12 February 2010 events, based on EHI, SRH, BRN, and MCAPE analyses. Conversely, topography around the 20 September 2011 event is characterized as the least significant factor based on EHI, SRH, BRN, and MCAPE analyses. The evaluation of absolute vorticity budget reveals that in all cases the simulations with topography are associated with higher values of maximum absolute vorticity in the area of interest than those without topography.

ii. Heat wave is commonly considered as a period of abnormally and uncomfortably hot weather with high air humidity. Typically, a heat wave lasts at least two days (Koppe et al., 2004). Nevertheless, a clear definition of heat waves has not yet been addressed by the World Meteorological Organization. Despite the fact that the heat wave concerns a meteorological phenomenon, it could not be assessed without reference to the related impacts on humans. So, it would be better to take into account the human sensation of heat against determining specific thresholds of meteorological parameters. Robinson (2001) considers a heat wave as an extended period of uncommonly high atmosphere-related heat stress, which causes temporary modifications in lifestyle habits and adverse health related problems affecting humans. It is very likely that heat waves will occur with a higher frequency and duration by late 21th century, due to global warming (Beniston et al., 2007; IPCC, 2013; Nastos and Kapsomenakis, 2015). A recent research has given evidence that "Mega-heat waves" such as the 2003 and 2010 events broke the 500 year long seasonal temperature records over approximately $50 \%$ of Europe (Barriopedro et al., 2011). Further, the extreme air tem- perature indices can be divided into three categories: absolute, percentile and duration indices, defined by the joint $\mathrm{CCl} / \mathrm{CLIVAR} / \mathrm{JCOMM}$ Expert Team (ET) on Climate Change Detection and Indices (Alexander et al., 2006). Five papers in the Special Issue analyze heat waves, urban heat island and extreme temperature indices, by utilizing both observations and models' simulations.

The predictability of the Russian heat wave during July and August of 2010 on a seasonal timescale is analyzed by Katsafados et al. (2014). The dynamical seasonal simulations have been carried out using the state-of-theart CAM3 AGCM, designed to produce simulations for several different dynamical cores and horizontal resolutions. The impact of various model initializations on the predictability of the event is also investigated because such comprehensive prognostic systems are sensitive to the initial conditions due to the chaotic nature of the atmosphere. The ensemble seasonal simulations are based on a modified version of the lagged-average forecast method using different lead-time initializations of the model. The results indicate that only a few individual members reproduce the main features of the blocking system 3 months ahead. Most members miss the phase space and the propagation of the system, setting limitations in the predictability of the event. The results of this study underline the main difficulties and limitations in the seasonal simulation of such high-impact weather event.

Giannaros et al. (2014) present the development of a high resolution heat island modeling system, which could be used in the context of operational real-time weather forecasting applications. The urban heat island (UHI) effect is one prominent form of localized anthropogenic climate modification. The modeling system is built around a state-of-the-art numerical weather prediction model, properly modified to allow for the better representation of the urban climate. The model performance in terms of simulating the near-surface air temperature and thermal comfort conditions over the complex urban area of Athens, Greece, is evaluated during a 1.5-month operational implementation in the summer of 2010. Results from this case study reveal an overall satisfactory performance of the modeling system. The discussion of the results highlights the important role that, given the necessary modifications and adaptations, meso-scale meteorological models constitute a promising tool for the operational simulation/forecasting of the urban thermal climate and thermal comfort conditions. Nevertheless, there is still room for improvement of the presented modeling system

Tolika et al. (2014) make an effort to identify the leading meteorological conditions over the Mediterranean as well as the corresponding large-scale atmospheric 
processes and key synoptic scale features that possibly contributed to such extreme winter cooling and summer warming in 2012 over Greece. During the summer and autumn months, numerous regions in the domain of study experienced record-breaking maximum and minimum temperatures. Conversely, the winter period was particularly cold and January one of the coldest months over the last 55 years. The analysis of the cold period indicates that the synoptic conditions resemble the positive phase of the Eastern Mediterranean Pattern (EMP). The predominance of these cool conditions seems to be related primarily to an intense NNW or NNE atmospheric circulation, as a consequence of the positive EMP phase. Moreover, the reduction in the floating sea ice emerges as a key driver of the formation of a low-pressure pattern and the reinforcement of the trough south of Scandinavia, which in turn strengthened the Siberia High east of the trough. This reinforcement resulted in a blocking pattern and in favorable conditions for the EMP formation. The atmospheric circulation during the prolonged high-temperature period resembles, respectively, the negative phase of North SeaCaspian Pattern teleconnection. The observed positive pole, in conjunction with the strong southwestern circulation, results in temperature increases and in the development of a smooth pressure field that contributes to the weakening of the Etesian winds and therefore to calm conditions over the continental areas.

The extreme temperature indices (ETCCDI; Expert Team on Climate Change Detection and Indices) in the Mediterranean region of Montenegro for the period of 1951-2010 are analyzed in terms of trends by Burić et al. (2014), using four stations in the coastal area of Montenegro - Herceg Novi, Ulcinj, Budva and Bar - within two periods (before 1980 and after 1980) due to a well-known climate shift that occurred in the late 1970s. A negative trend has been calculated for cold nights and cold days at almost all stations. The most significant trends are obtained for warm conditions over the investigated area during the period of 19512010. The trend found in this study can be associated with the positive phase of the North Atlantic Oscillation (NAO) since this pattern is recognized as the main mode of climate variability in the extratropical Northern Hemisphere. However, a separately investigated period of 1951-1980 for the region has shown opposite tendencies and a contrasting trend to the period of 19512010 as well as 1981-2010. This result is possibly due to a well-known climate shift that occurred in the late 1970s where there is a change in the sign of trend for warm days and warm nights. These two separately investigated periods have shown contrasting temperature trends.
The paper of Kostopoulou et al. (2014) presents the spatial patterns and temporal trends in temperature and precipitation and their extremes in the eastern Mediterranean and Middle East region (EMME), using output from the Hadley Centre PRECIS climate model. The evaluation results have shown that the model reproduces the major features of the observed annual cycle and provided evidence of the accuracy of the model results and associated uncertainties. The spatial distribution of recent temporal trends in temperature indicates strong increasing in minimum temperature over the eastern Balkan Peninsula, Turkey and the Arabian Peninsula. The rate of warming reaches $0.4-0.5^{\circ} \mathrm{Cdecade}^{-1}$ in a large part of the domain, while warming is expected to be strongest in summer $\left(0.6-0.7^{\circ} \mathrm{C}\right.$ decade $\left.^{-1}\right)$ in the eastern Balkans and western Turkey. The trends in annual and summer maximum temperature are estimated at approximately 0.5 and $0.6{ }^{\circ} \mathrm{Cdecade}^{-1}$ respectively. The trends in annual and summer maximum temperature are estimated at approximately 0.5 and 0.6 degreeC decade $^{-1}$ respectively. Recent estimates do not indicate statistically significant trends in precipitation except for individual sub-regions. Results indicate a future warming trend for the study area over the last 30 years of the 21 st century. Trends are estimated to be positive and statistically significant in nearly the entire region. The annual trend patterns for both minimum and maximum temperature show warming rates of approximately $0.4-0.6^{\circ} \mathrm{C}$ decade $^{-1}$, with pronounced warming over the Middle Eastern countries. Summer temperatures reveal a gradual warming $\left(0.5-0.9^{\circ} \mathrm{Cdecade}^{-1}\right)$ over much of the region. The model projects drying trends by $5-30 \%$ in annual precipitation towards the end of the 21 st century, with the number of wet days decreasing at the rate of $10-30$ days $\mathrm{yr}^{-1}$, while heavy precipitation is likely to decrease in the high-elevation areas by 15 days $\mathrm{yr}^{-1}$.

iii. Drought is a natural, casual and temporary state of continuous decline in precipitation and water availability in relation to normal values, spanning a considerable period and covers a wide area. It is discriminated into meteorological, hydrological and agricultural drought. It is a local phenomenon identified by the intensity, duration and extent. Drought impacts concern a variety of sectors of economy, environment and society of the affected area (Wang, 2005; Mechler et al., 2010; Dalezios et al., 2012). The identification of dry areas has been considered two millennia ago. The classical Greek thought acknowledged that the latitude affects the arid, temperate and cold zones of the earth. There was a perception that the arid climates in low latitudes were dry (Nastos et al., 2013). The evaluation of drought is accomplished by the drought indices, the most important of which and widely used are the Aridity Index (AI), which is based 
on the ratio of annual precipitation and potential evapotranspiration rates (UNESCO, 1979), the Standardized Precipitation Index (SPI), which is based on the probability of precipitation for any time scale (McKee et al., 1993), Palmer Drought Severity Index (PDSI), which is a soil moisture algorithm calibrated for relatively homogeneous regions (Palmer, 1965) and Reclamation Drought Index (RDI), which is based on a calculation of drought at the river basin level, incorporating temperature as well as precipitation, snowpack, stream flow and reservoir levels as input (Weghorst, 1996). Reconnaissance Drought Index (RDI) proposed by Tsakiris et al. (2007) is one of the most recent developments in the field of meteorological drought indices. Essentially, it relates precipitation to the potential evapotranspiration at a location, and can be considered as an extension of the SPI. The development of Earth observation satellites from the 1980s onwards promoted the drought monitoring and detection. The most prominent vegetation index is certainly the Normalized Difference Vegetation Index (NDVI; Tucker, 1979) that was first applied to drought monitoring by Tucker and Choudhury (1987). The index NDVI, by itself, does not depict drought or not drought conditions, but severity of drought can be defined as the deviation from the mean NDVI value of a long period (DEVNDVI). One paper in the Special Issue addresses the risk identification of agricultural drought.

Dalezios et al. (2014) deals with risk identification of agricultural drought, which involves drought quantification and monitoring, as well as statistical inference. For the quantitative assessment of agricultural drought, as well as the computation of spatiotemporal features, one of the most reliable and widely used indices is applied, namely the vegetation health index (VHI). The computation of VHI is based on satellite data of temperature and the normalized difference vegetation index (NDVI). The spatiotemporal features of drought, which are extracted from VHI, are areal extent, onset and end time, duration and severity. In this paper, a 20year (1981-2001) time series of the National Oceanic and Atmospheric Administration/advanced very high resolution radiometer (NOAA/AVHRR) satellite data is used, where monthly images of VHI are extracted. Application is implemented in Thessaly, which is the major agricultural drought-prone region of Greece, characterized by vulnerable agriculture. The results show that agricultural drought appears every year during the warm season in the region. The severity of drought is increasing from mild to extreme throughout the warm season, with peaks appearing in the summer. Similarly, the areal extent of drought is also increasing during the warm season, whereas the number of extreme drought pixels is much less than those of mild to moderate drought throughout the warm season. Finally, the areas with di- achronic drought persistence can be located. Drought early warning is developed using empirical functional relationships of severity and areal extent. The adopted remote-sensing data and methods have proven very effective in delineating spatial variability and features in drought quantification and monitoring.

iv. Heavy convective precipitation typically occurs with moist deep convection. The excess water vapor in rising air parcels condenses to form a cloud. The heat released through this condensation can help to sustain the convection by warming the air further and making it rise still higher, which causes more water vapor to condense, so the process feeds on itself. Doswell et al. (1996) have said that in order to produce moist deep convection three ingredients are needed: (1) the environmental lapse rate must be conditionally unstable, (2) there must be enough lifting so that a parcel will reach its level of free convection, (3) there must be enough moisture present that a rising parcel's associated moist adiabat has a level of free convection. In mid-latitudes, convective precipitation is associated with cold fronts (often behind the front), squall lines, and warm fronts in very moist air. Graupel and hail indicate convection. Besides, warm rain, precipitation produced solely through condensation and accretion of liquid, is known to be important in the tropics (Rogers, 1967; Houze, 1977). However, the warm rain process may also play a critical role in heavy convective precipitation events in midlatitudes as well, resulting in many flash floods and landslides. Four papers in the Special Issue investigate the flood risk, severe thunderstorms, rainfall intensity and landslides by implementing specific modelling and techniques.

The hydrological effects of multi-temporal land use changes in flood risk within the catchment area of Yialias River have been studied by Alexakis et al. (2014). They apply a hydrological model to simulate the main components of the hydrologic cycle, in order to study the diachronic effects of land use changes. For the implementation of the model, land use, soil and hydrometeorological data were incorporated. The climatic and stream flow data were derived from rain and flow gauge stations located in the wider area of the watershed basin. In addition, the land use and soil data were extracted after the application of object-oriented nearest neighbor algorithms of ASTER satellite images. Subsequently, the cellular automata (CA)-Markov chain analysis was implemented to predict the 2020 land use/land cover (LULC) map and incorporate it to the hydrological impact assessment. The preliminary results denoted the crucial role of urban sprawl phenomenon as well as the significant change of land cover regime in the increase of runoff rate within the spatial limits of a catchment area and highlighted the importance of searching 
land use regime with the use of satellite remote sensing imageries. In addition, the implementation of $\mathrm{CA}_{-}$ Markov provided indication of the potential impact of land use change on flood vulnerability in the near future.

An alternative methodological tool for the prediction of severe thunderstorms occurring over a specific area has been developed by Korologou et al. (2014). Northwestern Peloponnese is chosen to illustrate the proposed tool, because many thunderstorms with heavy rainfall have occurred there with disastrous impacts, for the period January 2006-June 2011. The synoptic scale circulation is examined throughout the troposphere along with satellite images, lightning data and synoptic observations of weather stations. Well-known instability indices are calculated and tested against synoptic observations. Taking into account the severity of the incidents, the performance of the indices was not as good as expected. Then, the Local Instability Index (LII) was inferentially drawn by using them. The LII is a threshold function that consists of the low-level moisture, a practical approximation of the CAPE, the terrain heating effect and a formalized operational experience. The results reveal that the LII has satisfactory total performance $(75 \%)$ over the northwestern Peloponnese.

Benhamrouche et al. (2015) assess the spatial and temporal distribution of the daily precipitation concentration index (CI) in Algeria (south Mediterranean Sea). $\mathrm{CI}$ is an index related to the rainfall intensity and erosive capacity; therefore, this index is of great interest for studies on torrential rainfall and floods. Forty-two daily rainfall series based on high-quality and fairly regular rainfall records for the period from 1970 to 2008 have been used. It is concluded that in Algeria, the essential features of climate in different regions are characterized by narrow climatic zones close to the coast, under the combined influence of the sea. The relief of the soil, the latitude and the diversity of climates in Algeria lead to a very different rainfall distribution. The daily precipitation CI results allowed the identification of three climate zones: the northern country, characterized by coastal regions with $\mathrm{CI}$ values between 0.59 and 0.63 ; the highlands, with values between 0.57 and 0.62 , except for the region of Biskra $(\mathrm{CI}=0.70)$; and the southern region of the country, with high rainfall concentrations with values between 0.62 and 0.69 .

An original approach to set up a mosaic of 18 local rainfall thresholds, in place of a single regional threshold, to be used in civil protection warning systems for the occurrence of landslides at regional scale is proposed by Segoni et al. (2014a). The proposed approach is based on the use of a software program named MaCumBA (explained and discussed in detail in Segoni et al., 2014b), which allows for statistical intensity-duration rainfall thresholds to be identified by means of an automated and standardized analysis of rainfall data. The automation and standardization of the analysis brings several advantages that in turn have a positive impact on the applicability of the thresholds to operational warning systems. Moreover, the possibility of defining a threshold in very short times compared to traditional analyses allows subdividing the study area into several alert zones to be analysed independently, with the aim of setting up a specific threshold for each of them. The authors focus on how the physical features of the test area influence the parameters and the equations of the local thresholds, and found that some threshold parameters can be put in relation with the prevailing lithology. In addition, the possible relations between effectiveness of the threshold and number of landslides used for the calibration are investigated. The findings of the study demonstrate that the effectiveness of a warning system can be significantly enhanced if a mosaic of site-specific thresholds is used instead of a single regional threshold.

v. Mediterranean Tropical Like Cyclones (TLC) known as Medicanes are meso-scale extreme low pressure systems, resembling the structure of tropical cyclones, as they captured by satellites. Their intensity appears much weaker than tropical hurricanes; however, some of them have reached tropical hurricane strengths. Emanuel (2005) indicated that their genesis is triggered when an upper-level cut-off low is advected over an area, resulting in air mass lifting and cooling causing convective instability. It is of high concern their structure and evolution (Pytharoulis et al., 2000; Homar et al., 2003; Moscatello et al., 2008), the model physics in simulating the structure and intensity (Miglietta et al., 2015). These meso-scale systems with diameter usually less than $300 \mathrm{~km}$ have a rounded structure and a warm core, as well as intense low sea level pressure (Businger and Reed, 1989). Strong winds, heavy precipitation and thunderstorms are associated with the incidence of medicanes, causing occasional severe damages in private property, agriculture and communication networks, or resulting in flooding of populated areas, posing a risk to human life (Nastos et al., 2015). Two papers in the Special Issue evaluate the simulations of medicanes and typhoons.

Akhtar et al. (2014) examine the ability of the coupled atmosphere-ocean model COSMO-CLM/1-D NEMOMED12 with atmospheric grid spacings of $0.44,0.22$, and $0.08^{\circ}$ (about 50, 25, and $9 \mathrm{~km}$, respectively) and an ocean grid spacing of $1 / 12^{\circ}$ to simulate 11 historical medicanes (Mediterranean hurricanes), which exhibit some similarities to tropical cyclones. The strong cyclonic winds associated with medicanes threaten the highly populated coastal areas around the Mediterranean basin. To reduce the risk of casualties and overall 
negative impacts, it is important to improve the understanding of medicanes with the use of numerical models. The results show that at high resolution, the coupled model is able to not only simulate most of medicane events but also improve the track length, core temperature, and wind speed of simulated medicanes compared to the atmosphere-only simulations. Besides, the coupled model is an effective tool for simulating extreme events such as medicanes. The presented coupled model can be a useful tool for studying tropicallike storms, particularly the ocean feedback effects. The impact of coupling on the vertical structures of medicanes and other important parameters such as precipitation and air-sea fluxes should be analyzed in detail. A full three-dimensional ocean model can be used for long-term climate simulations and future projections of these extreme events.

Haghroosta et al. (2014) have conducted numerical experiments using the Weather Research and Forecasting (WRF) model to determine the best combination of physics parameterization schemes for the simulation of sea surface temperatures, latent heat flux, sensible heat flux, precipitation rate, and wind speed that characterize typhoons. Through these experiments, several physics parameterization options are exhaustively tested for typhoon Noul, which originated in the South China Sea in November 2008. The model domain consists of one coarse domain and one nested domain. The resolution of the coarse domain is $30 \mathrm{~km}$, and that of the nested domain is $10 \mathrm{~km}$. The model simulation results are compared with the Climate Forecast System Reanalysis (CFSR) data set through the use of standard statistical measurements. The results facilitate the determination of the best combination of options suitable for predicting each physics parameter. Then, the suggested best combinations are examined for seven other typhoons and the solutions are confirmed. Finally, the best combination is compared with other introduced combinations for wind-speed prediction for typhoon Washi in 2011. The contribution of this study is to have attention to the heat fluxes besides the other parameters. Overall, the performance of the WRF model is acceptable and satisfactory for prediction of important parameters related to typhoon intensity over the South China Sea region.

vi. The frequency of large wildfires and the total area burned have been steadily increasing, with global warming being a major contributing factor. Drier conditions will increase the probability of fire occurrence. Longer fire seasons will result as spring runoff occurs earlier, summer heat builds up more quickly, and warm conditions extend further into fall (Running, 2006). More fuel for forest fires will become available because warmer and drier conditions are conducive to widespread beetle and other insect infestations, resulting in broad ranges of dead and highly combustible trees (Joyce et al., 2008). Increased frequency of lightning is expected as thunderstorms become more severe (Price, 2009). Heat waves, droughts, and cyclical climate changes such as El Niño can also have a dramatic effect on the risk of wildfires. Although, more than four out of every five wildfires are caused by people. There is a variety of fire danger rating systems used worldwide, including the Canadian Forest Fire Weather Index System (CFFWIS) used in Canada (van Wagner, 1987), the National Fire Danger Rating System (NFDRS) used in the USA (Deeming et al., 1977) and the McArthur Forest Fire Danger Index (FFDI) used in Australian forests (McArthur, 1967). In Europe, some well-known indices include the Finnish Fire Index (FFI), developed by the Finnish Meteorological Institute (Venäläinen and Heikinheimo, 2003); the Portuguese index (ICONA, 1988); and the Italian index (IREPI) proposed by Bovio et al. (1984). One paper in the Special Issue evaluates Canadian Fire Weather Index (FWI) over Greece.

Karali et al. (2014) evaluates the Canadian Fire Weather Index (FWI) over Greece. FWI is a daily meteorologically-based index designed in Canada and used worldwide (including the Mediterranean basin) to estimate fire danger in a generalized fuel type, based solely on weather observations. The evaluation of the FWI is performed using available current fire observations for Greece for a 15 year period and the index is confirmed to be capable of predicting fire occurrence. The critical threshold values of FWI for fire occurrence (one fire per day per area unit) vary spatially, increasing as we move from the northwest to the southeast of Greece. Three critical fire risk threshold values could be established: FWI $=15$ for western Greece, $\mathrm{FWI}=30$ for northern Greece and FWI $=45$ for eastern and southern Greece (including eastern continental areas, the large Aegean Sea islands and Crete). These thresholds are not applicable for the small Aegean islands due to the complex local terrain and the small number of fire events. Future fire risk projections suggest a general increase in fire risk over the domain of interest, with a very strong impact in the eastern Peloponnese, Attica, central Macedonia, Thessaly and Crete. In the near future, 15 to 20 additional critical fire risk days are expected in western and northern Greece. For eastern and southern Greece the increase reaches up to 10 days per year. For the distant future, the same pattern applies, with an increase of 30 to 40 days for western and northern Greece and 20 to 30 for eastern and southern Greece. 
Acknowledgements. The authors of this review article would like to thank the authors and co-authors of the papers included in this special issue, as well as the anonymous reviewers for their valuable comments and recommendations.

\section{References}

Akhtar, N., Brauch, J., Dobler, A., Béranger, K., and Ahrens, B.: Medicanes in an ocean-atmosphere coupled regional climate model, Nat. Hazards Earth Syst. Sci., 14, 2189-2201, doi:10.5194/nhess-14-2189-2014, 2014.

Alexakis, D. D., Grillakis, M. G., Koutroulis, A. G., Agapiou, A., Themistocleous, K., Tsanis, I. K., Michaelides, S., Pashiardis, S., Demetriou, C., Aristeidou, K., Retalis, A., Tymvios, F., and Hadjimitsis, D. G.: GIS and remote sensing techniques for the assessment of land use change impact on flood hydrology: the case study of Yialias basin in Cyprus, Nat. Hazards Earth Syst. Sci., 14, 413-426, doi:10.5194/nhess-14-413-2014, 2014.

Alexander, L. V., Zhang, X., Peterson, T. C., Caesar, J., Gleason, B., Klein Tank, A. M. G., Haylock, M., Collins, D., Trewin, B., Rahimzadeh, F., Tagipour, A., Rupa Kumar, K., Revadekar, J., Griffiths, G., Vincent, L., Stephenson, D. B., Burn, J., Aguilar, E., Brunet, M., Taylor, M., New, M., Zhai, P., Rusticucci, M., and Vazquez-Aguirre, J. L.: Global observed changes in daily climate extremes of temperature and precipitation, J. Geophys. Res., 111, D05109, doi:10.1029/2005JD006290, 2006.

Barriopedro, D., Fischer, E. M., Luterbacher, J., Trigo, R. M., and García-Herrera, R.: The Hot Summer of 2010: Redrawing the Temperature Record Map of Europe, Science, 332, 220-224, doi:10.1126/science.1201224, 2011.

Benhamrouche, A., Boucherf, D., Hamadache, R., Bendahmane, L., Martin-Vide, J., and Teixeira Nery, J.: Spatial distribution of the daily precipitation concentration index in Algeria, Nat. Hazards Earth Syst. Sci., 15, 617-625, doi:10.5194/nhess-15-617-2015, 2015.

Beniston, M., Stephenson, D. B., Christensen, O. B., Ferro, C. A. T., Frei, C., Goyette, S., Halsnaes, K., Holt, T., Jylhä, K., Koffi, B., Palutikof, J., Schöll, R., Semmler, T., and Woth, K.: Current and future extreme climatic events in Europe: observations and modeling studies conducted within the EU PRUDENCE project, Climatic Change, 81, 71-95, 2007.

Bovio, G., Quaglino, A., and Nosenzo, A.: Individuazione di un indice di previsione per il Pericolo di Incendi Boschivi, Monti e Boschi Anno, XXXV, 39-44, 1984.

Brázdil, R., Chromá, K., Dobrovolný, P., and Černoch, Z.: The tornado history of the Czech Lands, AD 1119-2010, Atmos. Res., 118, 193-204, 2012.

Burič, D., Lukovič, J., Bajat, B., Kilibarda, M., and Živkovič, N.: Recent trends in daily rainfall extremes over Montenegro (1951-2010), Nat. Hazards Earth Syst. Sci., 15, 2069-2077, doi:10.5194/nhess-15-2069-2015, 2015.

Businger, S. and Reed, R.: Cyclogenesis in cold air masses, Weather Forecast., 20, 133-156, 1989.

Dalezios, N. R., Blanta, A., and Spyropoulos, N. V.: Assessment of remotely sensed drought features in vulnerable agriculture, Nat. Hazards Earth Syst. Sci., 12, 3139-3150, doi:10.5194/nhess-123139-2012, 2012.
Dalezios, N. R., Blanta, A., Spyropoulos, N. V., and Tarquis, A. M.: Risk identification of agricultural drought for sustainable Agroecosystems, Nat. Hazards Earth Syst. Sci., 14, 2435-2448, doi:10.5194/nhess-14-2435-2014, 2014.

Deeming, J. E., Burgan, R. E., and Cohen, J. D.: The National FireDanger Rating System - 1978, USDA Forest Service General technical Report INT-39, Intermountain Forest and Range Experiment Station, Ogden, UT, 1977.

Doswell, C. A., Brooks, H. E. and Maddox, R. A.: Flash flood forecasting: An ingredients based methodology, Weather Forecast., 11, 560-581, 1996.

Dotzek, N.: An updated esti mate of tornado occurrence in Europe, Atmos. Res., 67-68, 153-161, 2003.

Emanuel, K.: Genesis and maintenance of "Mediterranean hurricanes", Adv. Geosci., 2, 217-220, doi:10.5194/adgeo-2-2172005, 2005.

Fujita, T. T.: Tornadoes around the world, Weatherwise, 26, 56-83, 1973.

Gayà, M., Homar, V., Romero, R., and Ramis, C.: Tornadoes and waterspouts in the Balearic Islands: Phenomena and environment characterization, Atmos. Res., 56, 253-267, 2000.

Giannaros, T. M., Melas, D., Daglis, I. A., and Keramitsoglou, I.: Development of an operational modeling system for urban heat islands: an application to Athens, Greece, Nat. Hazards Earth Syst. Sci., 14, 347-358, doi:10.5194/nhess-14-347-2014, 2014.

Haghroosta, T., Ismail, W. R., Ghafarian, P., and Barekati, S. M.: The efficiency of the Weather Research and Forecasting (WRF) model for simulating typhoons, Nat. Hazards Earth Syst. Sci., 14, 2179-2187, doi:10.5194/nhess-14-2179-2014, 2014.

Homar, V., Romero, R., Stensrud, D. J., Ramis, C., and Alonso, S.: Numerical diagnosis of a small, quasi-tropical cyclone over the western Mediterranean: Dynamical vs. boundary factors, Q. Roy. Meteorol. Soc., 129, 1469-1490, 2003.

Houze, R. A.: Structure and dynamics of a tropical squall-line system, Mon. Weather Rev., 105, 1540-1567, 1977.

ICONA: Experimentacion de un nuevo sistema para determinacion del peligro de incendios forestales derivado de los combustibles:instrucciones de calculo, Instituto Nacional para la Conservacion de la Naturaleza, Madrid, Spain, 1988.

IPCC: Managing the Risks of Extreme Events and Disasters to Advance Climate Change Adaptation. A Special Report of Working Groups I and II of the Intergovernmental Panel on Climate Change, edited by: Field, C. B., Barros, V., Stocker, T. F., Qin, D., Dokken, D. J., Ebi, K. L., Mastrandrea, M. D., Mach, K. J., Plattner, G.-K., Allen, S. K., Tignor, M., and Midgley, P. M., Cambridge University Press, Cambridge, UK, and New York, NY, USA, 582 pp., 2012.

IPCC: Summary for Policymakers, in: Climate Change 2013, The Physical Science Basis, Contribution of Working Group I to the Fifth Assessment Report of the Intergovernmental Panel on Climate Change, Cambridge University Press, Cambridge, UK and New York, NY, USA, 2013.

Joyce, L. A., Blate, G. M., Littell, J. S., McNulty, S. G., Millar, C. I., Moser, S. C., Neilson, R. P., O'Halloran, K., and Peterson, D. L.: National Forests, in: Preliminary review of adaptation options for climate-sensitive ecosystems and resources, A Report by the U.S. Climate Change Science Program and the Subcommittee on Global Change Research, US Environmental Protection Agency, Washington, D.C., USA, 3-1-3-127, 2008. 
Karali, A., Hatzaki, M., Giannakopoulos, C., Roussos, A., Xanthopoulos, G., and Tenentes, V.: Sensitivity and evaluation of current fire risk and future projections due to climate change: the case study of Greece, Nat. Hazards Earth Syst. Sci., 14, 143-153, doi:10.5194/nhess-14-143-2014, 2014.

Katsafados, P., Papadopoulos, A., Varlas, G., Papadopoulou, E., and Mavromatidis, E.: Seasonal predictability of the 2010 Russian heat wave, Nat. Hazards Earth Syst. Sci., 14, 1531-1542, doi:10.5194/nhess-14-1531-2014, 2014.

Koppe, C., Jendritzky, G., Kovats, S., and Menne, B.: Heat-waves: risks and responses, Series No. 2, Regional Office for Europe, Health and Global Environmental Change, Kopenhagen, Denmark, 2004.

Korologou, M., Flocas, H., and Michalopoulou, H.: Developing an index for heavy convective rainfall forecasting over a Mediterranean coastal area, Nat. Hazards Earth Syst. Sci., 14, 22052214, doi:10.5194/nhess-14-2205-2014, 2014.

Kostopoulou, E., Giannakopoulos, C., Hatzaki, M., Karali, A., Hadjinicolaou, P., Lelieveld, J., and Lange, M. A.: Spatio-temporal patterns of recent and future climate extremes in the eastern Mediterranean and Middle East region, Nat. Hazards Earth Syst. Sci., 14, 1565-1577, doi:10.5194/nhess-14-1565-2014, 2014.

Macrinoniene, I.: Tornadoes in Lithuania in the period of 19502002 including analysis of the strongest tornado of 29 May 1981, Atmos. Res., 67-68, 475-484, 2003.

Matsangouras, I. T., Nastos, P. T., Bluestein, H. B., and Sioutas, M. V.: A climatology of tornadic activity over Greece based on historical records, Int. J. Climatol., 34, 2538-2555, 2014 a.

Matsangouras, I. T., Pytharoulis, I., and Nastos, P. T.: Numerical modeling and analysis of the effect of complex Greek topography on tornadogenesis, Nat. Hazards Earth Syst. Sci., 14, 1905-1919, doi:10.5194/nhess-14-1905-2014, 2014b.

McArthur, A. G.: Fire Behaviour in Eucalypt Forests, Department of National Development, Leaflet No. 107, Forestry and Timber Bureau, Canberra, Australia, 1967.

McKee, T. B., Doesken, N. J. and Kleist, J.: The relationship of drought frequency and duration to time scale, in: Preprints Eighth Conference on Applied Climatology, 17-22 January 1993, American Meteorological Society, Anaheim, CA, 179-184, 1993.

Meaden, G. T.: Tornadoes in Britain: Their intensities and distribution in space and time, J. Meteorol., 1, 242-251, 1976.

Mechler, R., Hochrainer, S., Aaheim, A., Salen, H., and Wreford, A.: Modelling economic impacts and adaptation to extreme events: Insights from European case studies, Mitig. Adapt. Strat. Global Change, 15, 737-762, 2010.

Miglietta, M. M., Mastrangelo, D., and Conte, D.: Influence of physics parameterization schemes on the simulation of a tropicallike cyclone in the Mediterranean Sea, Atmos. Res., 153, 360$375,2015$.

Moscatello, A., Miglietta, M. M., and Rotunno, R.: Numerical analysis of a Mediterranean 'hurricane' over southeastern Italy, Mon. Weather Rev., 136, 4373-4397, 2008.

Nastos, P. T. and Kapsomenakis, J.: Regional climate model simulations of extreme air temperature in Greece. Abnormal or common records in the future climate?, Atmos. Res., 152, 43-60, 2015.
Nastos, P. T. and Matsangouras, I. T.: Tornado activity in Greece within the 20th Century, Adv. Geosci., 26, 49-51, doi:10.5194/adgeo-26-49-2010, 2010.

Nastos, P. T. and Matsangouras, I. T.: Analysis of synoptic conditions for tornadic days over western Greece, Nat. Hazards Earth Syst. Sci., 14, 2409-2421, doi:10.5194/nhess-14-24092014, 2014.

Nastos, P. T., Politi, N., and Kapsomenakis, J.: Spatial and temporal variability of the Aridity Index in Greece, Atmos. Res., 119, 140 152, 2013.

Nastos, P. T., Karavana-Papadimou, K., and Matzangouras, I. T.: Tropical-like cyclones in the Mediterranean: Impacts and composite daily means and anomalies of synoptic conditions, Proceedings of the 14th International Conference on Environmental Science and Technology, 3-5 September 2015, Rhodes, Greece, CEST2015_00407, 2015.

Palmer, W. C.: Meteorological drought, Research Paper No. 45, US Department of Commerce Weather Bureau, Washington, D.C., 1965.

Peterson, R. E.: A historical review of tornadoes in Italy, J. Wind Eng. Ind. Aerod., 74-76, 123-130, 1998.

Price, C.: Thunderstorms, Lightning and Climate Change, in: Lightning: Principles, Instruments and Applications, edited by: Betz, H. D., Schumann, U., and Laroche, P., Springer Publications, Berlin, 521-536, 2009.

Pytharoulis, I., Craig, G. C., and Ballard, S. P.: The hurricanelike Mediterranean cyclone of January 1995, Meteorol. Appl., 7, 261-279, 2000.

Rahuala, J., Brooks, E. H., and Schultz, M. D.: Tornado climatology of Finland, Mon. Weather Rev., 140, 1446-1456, 2012.

Reynolds, D. J.: A revised U.K. tornado climatology, 1960-1989, J. Meteorol., 24, 290-321, 1999.

Robinson, P. J.: On the definition of heat waves, J. Appl. Meteorol., 40, 762-775, 2001.

Rogers, R.: Doppler radar investigation of Hawaiian rain, Tellus, 19, 432-454, 1967.

Running, S. W.: Is Global Warming Causing More, Larger Wildfires?, Science, 313, 927-928, 2006.

Salinger, J., Sivakumar, M. V. K., and Motha, R. P. (Eds.): Increasing Climate Variability and Change: Reducing the Vulnerability of Agriculture and Forestry, Springer, Berlin, p. 362, 2005.

Segoni, S., Rosi, A., Rossi, G., Catani, F., and Casagli, N.: Analysing the relationship between rainfalls and landslides to define a mosaic of triggering thresholds for regional-scale warning systems, Nat. Hazards Earth Syst. Sci., 14, 2637-2648, doi:10.5194/nhess-14-2637-2014, 2014a.

Segoni, S., Rossi, G., Rosi, A., and Catani, F.: Landslides triggered by rainfall: a semi-automated procedure to define consistent intensity-duration thresholds, Comput. Geosci., 63, 123131, 2014b.

Smith, K.: Environmental Hazards: Assessing Risk and Reducing Disaster, 6th Edition, Routledge, New York, 478 pp., 2013.

Tolika, K., Maheras, P., Pytharoulis, I., and Anagnostopoulou, C.: The anomalous low and high temperatures of 2012 over Greece - an explanation from a meteorological and climatological perspective, Nat. Hazards Earth Syst. Sci., 14, 501-507, doi:10.5194/nhess-14-501-2014, 2014.

Tooming, H. K., Kotli, H., and Peterson, R. E.: Vigorous tornadoes and waterspouts during the last 35 years in Estonia, Meteorol- 
ogy in Estonia in Johannes Letzmann's Times and Today, edited by: Eelsalu, H., and Tooming, H., Estonian Academy Publishers, Tallinn, Estonia, 168-179, 1995.

Tsakiris, G., Pangalou, D., and Vangelis, H.: Regional drought assessment based on the Reconnaissance Drought Index (RDI), Water Resour. Manage., 21, 821-833, 2007.

Tucker, C. J.: Red and photographic infrared linear combinations for monitoring vegetation, Remote Sens. Environ., 8, 127-150, 1979.

Tucker, C. J. and Choudhury, B. J.: Satellite remote sensing of drought conditions, Remote Sens. Environ., 23, 243-251, 1987.

Tyrrell, J.: A tornado climatology for Ireland, Atmos. Res., 67-68, 671-684, 2003.

UNESCO - United Nations Educational, Scientific and Cultural Organization: Map of the world distribution of arid regions: Map at scale $1: 25,000,000$ with explanatory note, MAB Technical Notes 7, UNESCO, Paris, 1979. van Wagner, C. E.: Development and structure of a Canadian forest fire weather index system, Forestry Tech. Rep. 35, Canadian Forestry Service, Ottawa, 1987.

Venäläinen, A. and Heikinheimo, M.: The Finnish forest fire index calculation system, in: Early warning systems for natural disaster reduction, edited by: Zschau, J. and Kuppers, A., Springer, Berlin, 645-648, 2003.

Wang, G.: Agricultural drought in a future climate: Results from 15 global climate models participating in the IPCC 4th assessment, Clim. Dynam., 25, 739-753, 2005.

Weghorst, K.: The reclamation drought index: Guidelines and practical applications, Bureau of Reclamation, Denver, CO, $6 \mathrm{pp}$. 1996.

WMO - World Meteorological Organization: Preventing and mitigating natural disasters, WMO-No. 993, Geneva, 2006. 